\title{
Pengalaman Wanita Korban Intimate Partner Violence (IPV) yang Bertahan pada Hubungan Penuh Kekerasan
}

\author{
NIRVA ADEYUSTA REVAUGHANII \& WIWIN HENDRIANI*
}

Departemen Psikologi Pendidikan dan Perkembangan, Fakultas Psikologi Universitas Airlangga

\begin{abstract}
ABSTRAK
Penelitian ini bertujuan untuk mengetahui bagaimana gambaran pengalaman wanita korban intimate partner violence (IPV) yang bertahan dalam hubungan penuh kekerasan, alasan bertahan, dan pemaknaan terhadap kekerasan. Metode yang digunakan adalah metode penelitian kualitatif dengan pendekatan fenomenologis. Penelitian ini menggunakan wawancara dan observasi untuk mengumpulkan data. Teknik pencarian partisipan menggunakan teknik purposif. Partisipan sebanyak 3 orang dengan rentang usia 21-23 tahun. Teknik analisis data menggunakan Interpretative Phenomenological Analysis (IPA) dengan tahapan sebagai berikut: menyusun transkrip wawancara, membuat catatan awal, membuat komentar eksploratoris, membuat tema superordinat, dan melaporkan hasil. Hasil penelitian ini menemukan bahwa pengalaman wanita korban IPV yang bertahan pada hubugan penuh kekerasan tidak dapat dilepaskan dari bagaimana mereka mempersepsikan dan memaknai kekerasan yang dialami. Ditemukan adanya pemaknaan positif terhadap kekerasan seperti bentuk kasih sayang, upaya melindungi, dan mengubah wanita menjadi lebih baik. Keputusan bertahan juga diperkuat dengan beberapa alasan seperti cinta, faktor keluarga, dan keyakinan bahwa pasangan akan berubah.
\end{abstract}

Kata kunci: fenomenologi, kekerasan pasangan intim

\begin{abstract}
This study aims to find how the experience of women victims of IPV who stays in, reasons for surviving, and meaning of violence. The method used is qualitative research method with phenomenological approach. Interviews and observations are used to collect data. Sampling technique uses purposive technique. The sample consists of 3 people aged 21-23 years. Interpretative Phenomenological Analysis is used as data analysis technique with the following stages: compiling interview transcripts, making initial notes, making exploratory comments, making superordinate themes, and reporting results. Based on this study results, the women victims of IPV who stays in cannot be separated from how they perceive and interpret violence they experienced. There are positive meanings of violence such as forms of affection, effort to protect, and to change women for the better. The decision to stay is also strengthened by several reasons such as love, family factors, and belief that partner will change.
\end{abstract}

Keywords: intimate partner violence, phenomenological 


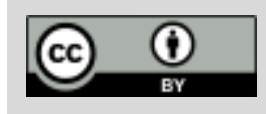

Naskah ini merupakan naskah dengan akses terbuka dibawah ketentuan the Creative Common Attribution License (CC-BY-4.0) (http://creativecommons.org/licenses/by/4.0), sehingga penggunaan, distribusi, reproduksi dalam media apapun atas artikel ini tidak dibatasi, selama sumber aslinya disitir dengan baik.

\section{P E N D A H U L U A N}

Setiap hal yang ada di muka bumi ini diciptakan berpasang-pasangan, seperti siang dan malam, matahari dan bulan, serta pria dan wanita. Setiap manusia juga diciptakan untuk memiliki beberapa jenis hubungan satu sama lain. Seperti hubungan dengan orang tua, hubungan dengan anak, hubungan dengan rekan kerja, hubungan dengan teman, bahkan hubungan dengan pacar. Memiliki hubungan satu sama lain membantu seseorang untuk lebih memahami hal-hal yang terjadi di sekitar mereka (Stenberg \& Weis, 2006). Hubungan-hubungan seperti ini dapat disebut dengan hubungan pasangan intim atau intimate partner relationship. Sebuah hubungan dapat dikatakan intim jika memiliki enam komponen yaitu pengetahuan, kepedulian, saling ketergantungan, kebersamaan, kepercayaan, dan komitmen (Brehm, Miller, Pelman, \& Campbell, 2002). Intimate Partner Relationship kerap pula dikaitkan dengan cinta dan hubungan romantis. Namun dalam sejumlah kasus yang datanya akan diuraikan kemudian, pada sebuah hubungan juga memiliki banyak sisi gelap mulai dari pertikaian kecil hingga terjerat dalam dinamika yang merusak dan berpotensi pada kerusakan serius terhadap satu sama lain, salah satunya Intimate Partner Violence atau kekerasan pasangan intim.

Intimate Partner Violence (IPV) atau kekerasan pasangan intim menggambarkan kekerasan fisik, psikologis/emosional, seksual dan/atau finansial yang biasanya diarahkan pada seorang wanita dan dilakukan oleh pasangan intim, baik pacar ataupun suami. Kekerasan fisik merupakan salah satu bentuk intimate partner violence dan merupakan cedera yang sengaja ditimbulkan sehingga menyebabkan adanya kerusakan tubuh. Kekerasan fisik dapat terjadi sendiri atau bersama dengan pelecehan seksual, penelantaran, atau kekerasan emosional (Carr, 2005). Hal ini merupakan salah satu masalah paling mendesak yang dihadapi perempuan di dunia. Berdasarkan tinjauan global 2013 yang dilakukan oleh WHO, hingga 70\% perempuan di seluruh dunia telah mengalami berbagai bentuk pelecehan seumur hidup mereka di tangan pasangan intim (World Health Organization, 2013). Hasil Survei Demografi dan Kesehatan Nasional 2013 di Filipina melaporkan bahwa satu dari lima wanita berusia 15 hingga 49 tahun telah mengalami kekerasan fisik dari pasangannya. Sepanjang periode 10 tahun dari 2004 hingga 2014, kasus kekerasan ini terus meningkat dari 218 kasus di 2004 menjadi 16.517 kasus di 2013 (Estrellado \& Loh, 2016).

Merujuk pada data survei Kementerian Pemberdayaan Perempuan dan Perlindungan Anak (KemenPPPA) pada tahun 2016 diketahui sebanyak 33,4\% perempuan di Indonesia dengan usia 15-64 tahun telah mengalami kekerasan fisik dan/atau kekerasan seksual selama hidupnya, dengan jumlah kekerasan fisik sebanyak 18,1\% dan kekerasan seksual 24,2\%. Simfoni PPA tahun 2016 menyebutkan bahwa dari 10.847 pelaku kekerasan, sebanyak 2.090 pelaku kekerasan adalah pacar (Kementrian Pemberdayaan Perempuan dan Perlindungan Anak, 2018). Angka kekerasan pada perempuan selalu meningkat setiap tahunnya, hal ini telah disiarkan dalam Siaran Pers Catatan Tahunan (CATAHU) Komnas Perempuan 2019 yang menunjukkan data pengaduan kasus kekerasan terhadap perempuan pada tahun 2018 mengalami peningkatan sebesar 14\% dari tahun sebelumnya. Tercatat terdapat 406.178 kasus (naik dari tahun 2017 sebanyak 348.466 kasus), dengan presentase tertinggi adalah kekerasan fisik sebesar 41\% dan kekerasan dalam pacaran merupakan kasus tertinggi kedua setelah kekerasan dalam rumah tangga (Komisi Nasional Anti Kekerasan Terhadap Perempuan, 2019). 
Menerima tindak kekerasan dari pasangan intim merupakan kejadian negatif dalam hidup. Hal ini dapat membuat wanita dilema untuk meninggalkan atau justru bertahan dalam hubungan penuh kekerasan. Seorang wanita akan meninggalkan hubungan yang penuh kekerasan karena adanya kesadaran bahwa dirinya sudah merasa lelah, sakit yang amat sangat, dan tidak ingin hidup dengan kekerasan terus menerus. Sedangkan beberapa wanita yang memilih bertahan menunjukkan adanya strategi coping yang baik (Putriana, 2018). Bertahan dalam hubungan penuh kekerasan tentu bukanlah hal yang mudah dan memiliki konsekuensi. Wanita yang memilih untuk bertahan dalam hubungan tersebut akan merasa kehilangan kontrol akan dirinya sendiri. Mereka menyatakan pandangan bahwa harga diri mereka memburuk sebagai akibat dari pelecehan terus-menerus dari pasangan mereka. Selain dari penganiayaan fisik, penghinaan, dan kata-kata merendahkan membuat mereka percaya bahwa mereka merasa seperti budak yang harus mengikuti apa yang diperintahkan oleh pasangan mereka. Sebagian besar wanita juga percaya bahwa mereka telah kehilangan peluang untuk kehidupan yang lebih baik serta kehilangan ketenangan akan pikiran mereka. Para korban merasa seperti kehilangan akal sehat, mengalami perasaan sangat gugup karena alasan yang tidak bisa mereka jelaskan, bahkan ada korban yang merasa menjadi gila (Estrellado \& Loh, 2016).

Meskipun beberapa penelitian menunjukkan bahwa bertahan dalam hubungan yang penuh kekerasan membawa dampak negatif bagi kondisi korban, masih banyak wanita yang menganggap bahwa kekerasan merupakan salah satu cara pasangannya untuk menunjukkan cintanya. Korban beranggapan bahwa kekerasan yang dialami tidak terlalu buruk. Korban juga memilih bertahan dalam hubungan yang penuh kekerasan karena menganggap dirinya yang paling memahami, mampu melindungi, dan bertanggung jawab terhadap kehidupan pasangan, sehingga korban memiliki harapan akan adanya perubahan pada perilaku pasangan. Dengan demikian korban tetap bersikap baik serta memberikan perhatian dan cinta yang besar pada pelaku (Sekarline \& Margaretha, 2013).

Dari beberapa fakta yang telah dipaparkan di atas, dapat disimpulkan bahwa wanita masih kerap menjadi korban kekerasan pasangan intim khususnya pacaran. Hal ini menarik perhatian penulis untuk meneliti bagaimana pengalaman bertahan dalam hubungan penuh kekerasan, alasan bertahan dalam hubungan penuh kekerasan, dan bagaimana pemaknaan kekerasan tersebut bagi korban. Setelah mengetahui bagaimana pengalaman, alasan, dan pemaknaan, penulis berharap dapat melihat fenomena dari kacamata yang berbeda dari penelitian sebelumnya.

\section{Desain Penelitian}

\section{E T O D E}

Penelitian ini menggunakan penelitian kualitatif dengan pendekatan fenomenologis. Pendekatan fenomenologis dipilih karena menurut Cresweell pendekatan fenomenologis dapat menjelaskan struktur kesadaran dalam pengalaman manusia. Melalui "pertanyaan pancingan", subjek penelitian dibiarkan menceritakan segala macam dimensi pengalamannya yang berkaitan dengan fenomena/peristiwa (Hasbiansyah, 2008). Oleh karena itu, pada penelitian ini peneliti akan menggunakan penelitian kualitatif dengan pendekatan fenomenologis untuk mengetahui bagaimana pengalaman dan pemaknaan sebuah fenomena kekerasan pasangan intim bagi seorang wanita yang bertahan pada hubungan penuh kekerasan.

\section{Partisipan}

Penelitian ini menggunakan teknik purposif untuk menentukan partisipan. Partisipan tidak diambil secara acak melainkan dipilih mengikuti kriteria tertentu. Adapun beberapa kriteria partisipan yang peneliti tetapkan adalah sebagai berikut: wanita berusia 21-23 tahun; merupakan korban kekerasan fisik; memiliki pasangan intim, khususnya pacar; mampu berkomunikasi dengan baik. 


\section{Strategi Pengumpulan Data}

Data dalam penelitian ini dikumpulkan dengan teknik wawancara dan observasi. Wawancara dalam studi fenomenologi mencakup pertanyaan yang dibutuhkan dan bergantung pada partisipan untuk mendiskusikan bagaimana partisipan memaknai pengalaman mereka. Proses wawancara ini menggunakan pedoman umum dengan tema-tema yang telah peneliti tentukan yang kemudian dikembangkan dengan jawaban partisipan, yang secara garis besar berkaitan dengan pengalaman yang dialami oleh wanita korban kekerasan pasangan intim khususnya pacaran.

Observasi digunakan sebagai pelengkap data wawancara terkait pengalaman kekerasan yang dialami oleh partisipan. Dalam penelitian ini peneliti berpartisipasi aktif dalam setting yang diamati dan dilakukan secara tidak terbuka (terselubung). Observasi tidak terbuka dilakukan agar partisipan tidak merasa sedang diamati sehingga dapat bertingkah laku biasa (tidak dibuat-buat atau disesuaikan dengan harapan sosial). Hal ini akan memungkinkan peneliti menangkap kejadian yang sesungguhnya.

\section{Analisis Data}

Penelitian ini menggunakan analisis data fenomenologis interpretatif atau interpretative phenomenological analysis (IPA) yang dikemukan oleh Edmund Husserl dan dikembangkan oleh Martin Heidegger dengan langkah sebagai berikut: (1) peneliti menyusun transkripsi hasil wawancara; (2) membuat catatan-catatan awal (initial noting), peneliti membuat catatan-catatan awal dengan memberi komentar-komentar eksploratoris yang berisi pernyataan interpretatif peneliti terhadap pernyataan partisipan yang dirasakan penting dalam transkrip; (3) membuat tema emergen dengan tujuan memadatkan komentar eksploratoris, tema berupa kata atau frasa; (4) membuat tema superordinat yang menampung beberapa tema emergen yang memiliki kemiripan makna; (5) melaporkan hasil penelitian (Kahija, 2017) .

\section{HAS I L P EN EL I T I A N}

\section{Pengalaman subjek 1}

Subjek DA kerap mendapatkan kekerasan pasangan intim yang dilakukan oleh pacar subjek berupa kekerasan verbal dan kekerasan fisik. Subjek kerap mendapatkan kekerasan verbal seperti "pelacur". Subjek juga diperlakukan seperti pelacur oleh pasangan. Pasangan pernah melempar sejumlah uang pada subjek setelah melakukan hubungan intim. Subjek mengatakan bahwa kekerasan verbal merupakan hal yang normal sehingga subjek tidak terlalu memikirkan hal tersebut. Hal ini menunjukkan adanya kesalahan berpikir pada subjek. Pertemanan subjek juga dibatasi oleh pasangan, karena pasangan selalu cemburu ketika subjek berkomunikasi dengan lawan jenis. Hal ini menunjukkan adanya relasi sosial yang terganggu. Kemudian subjek juga mendapatkan kekerasan fisik seperti tamparan, jambakan, gigitan, cubitan, dan pukulan. Subjek kerap mengulangi kata "dijambak", "nampar", "nyubit", dan "dipukul" yang menunjukkan bahwa tindakan tersebut merupakan tindakan kekerasan yang kerap diterima. Subjek mendapatkan pukulan pada bola mata sebelah kiri hingga terjadinya pendarahan dan kepala yang dibenturkan pada jendela mobil. Ketika mendapatkan perilaku kekerasan, awalnya subjek kebingungan mengapa subjek bisa mendapatkan pukulan hanya karena masalah sepele yang membuat sering munculnya pertanyaan untuk diri subjek sendiri, seperti "kenapa sih aku dipukulin?", "aku kurang baik ta buat dia?". Hal ini menunjukkan adanya pikiran berulang pada subjek. Namun subjek kerap mengabaikan pikiran dan perasaan tersebut agar subjek tidak kepikiran. Subjek jarang untuk memberikan perlawanan namun terkadang memberikan perlawanan ketika merasa kesakitan. Hal ini subjek lakukan sebagai upaya melindungi diri. Meskipun ketika memberikan perlawanan, subjek mendapatkan tindakan yang lebih keras dari pasangan.

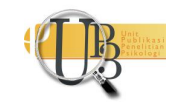




\section{Pengalaman Subjek 2}

Subjek HF lebih sering mendapatkan mental abuse dibandingkan kekerasan fisik, namun subjek juga pernah mendapatkan kekerasan fisik. Kekerasan berawal ketika subjek mendapatkan sebuah proyek kampus yang harus diselesaikan bersama dengan teman-teman subjek. Pasangan subjek meminta subjek agar pasangan subjek terlibat dalam proyek tersebut, namun subjek menolak. Ketika mengeluarkan argumentasi, subjek mendapatkan tindakan kekerasan berupa tamparan dari pasangan. Tamparan tersebut merupakan tamparan pertama yang subjek dapatkan dari seorang laki-laki. Setelah kejadian tersebut, pasangan subjek memaksa subjek untuk menjauhi teman-teman subjek karena pasangan subjek tidak menyukai teman-teman subjek. Subjek juga kerap dipaksa melakukan diet dan memakai pakaian terbuka. Ketika menceritakan pengalaman-pengalaman tersebut, intonasi subjek meningkat. Hal ini menunjukkan adanya guncangan emosional yang dialami oleh subjek.

Subjek mengetahui bahwa pasangan subjek sedang keluar bersama wanita lain. Sejak saat itu subjek menyadari bahwa pasangan subjek telah berselingkuh. Kemudian subjek dan pasangan bertengkar hebat dan subjek meminta untuk mengakhiri hubungan tersebut. Namun subjek justru mendapatkan tamparan dan jambakan, karena pasangan subjek tidak mau untuk mengakhiri hubungan tersebut. Setelah melakukan tindakan kekerasan tersebut, pasangan subjek merasa lemas dan sangat menyesal. Merasa iba ketika melihat keaadan pasangan subjek, subjek memilih untuk memaafkan dan kembali pada pasangan. Adanya pemafaan pada subjek menunjukkan bahwa subjek dapat menerima perilaku pasangan.

Subjek kerap meminta maaf kepada siapapun tanpa sebab. Hal ini dikarenakan subjek selalu takut untuk melakukan sesuatu. Subjek merasa bahwa orang-orang sekitar akan marah kepada subjek jika melakukan sesuatu. Subjek terbiasa meminta maaf karena ketika pasangan subjek marah kepada subjek, subjek segera meminta maaf untuk meredam emosi pasangan. Terkadang ketika tidak sedang bersama pasangan, subjek juga memiliki rasa dendam pada pasangan. Hal ini menunjukkan perilaku dan perasaan yang dipengaruhi oleh tindakan kekerasan yang diterima subjek. Bertahan dalam hubungan yang penuh kekerasan merupakan hal yang sulit bagi subjek. Hal ini menyebabkan subjek pernah menarik diri dari lingkungan sosial, menyilet tangan, dan memiliki pikiran untuk bunuh diri. Subjek sempat merasa depresi dan tertekan.

\section{Pengalaman Subjek 3}

Menjalin hubungan dengan pasangan selama satu setengah tahun merupakan hubungan yang penuh emosional bagi subjek AS. Subjek AS mendapatkan tindakan kekerasan setelah satu bulan berpacaran. Sejak awal mengenal pasangan, subjek sudah merasakan ada sesuatu yang janggal dari pasangan. Subjek dan pasangan subjek sering berselisih mengenai hal sepele, pasangan subjek mulai membentak subjek. Namun subjek mengabaikan hal tersebut dan tetap ingin mengenal pasangan lebih dalam.

Bagi subjek pasangan subjek sangatlah overprotective. Subjek harus melaporkan semua kegiatan serta dimana subjek berada. Subjek juga tidak boleh bermain sosial media dan berteman dengan lawan jenis. Subjek hanya boleh bepergian dengan pasangan dan keluarga subjek. Hal tersebut membuat subjek tidak ingin kuliah dan bersosialisasi. Subjek sempat mengambil cuti kuliah selama satu semester karena subjek selalu ditelpon ketika sedang melaksanakan kelas. Subjek menjadi tidak fokus dan merasa selalu dibatasi. Kemudian subjek setiap hari melakukan konseling dengan psikolog hingga meminta bantuan pada psikolog untuk mengubah perilaku pasangan.

Subjek juga kerap mendapatkan kekerasan verbal berupa "goblok", "gapunya otak", dan "lonte". Dan kekerasan fisik berupa pukulan, benturan, injakan, serta tangan dan kaki subjek ditempelkan dengan benda panas hingga kulit subjek mengelupas. Meskipun intontasi subjek meningkat ketika bercerita mengenai pengalaman subjek, subjek menganggap bahwa lebih baik kesakitan secara fisik daripada

Buletin Riset Psikologi dan Kesehatan Mental (BRPKM)

2021, Vol. 1(1), 149-161 
adanya perselingkuhan. Maka dari itu subjek selalu menerima perilaku pasangan. Subjek kerap mengabaikan perasaan dan rasa sakit yang subjek rasakan.

Ketika mendapatkan tindakan kekerasan, subjek tidak pernah bisa memberikan perlawanan. Hal tersebut dikarenakan subjek merasa iba dengan pasangan, subjek tidak pernah tega untuk menyakiti pasangan. Subjek hanya melakukan pengabaian pada pasangan dengan cara memutus komunikasi selama beberapa hari. Ketika memutuskan komunikasi tersebut, subjek mendapatkan teror berupa panggilan dari beberapa nomor tidak dikenal. Hal tersebut membuat subjek hingga saat ini merasa ketakutan ketika mendapatkan panggilan dari nomor tidak dikenal.

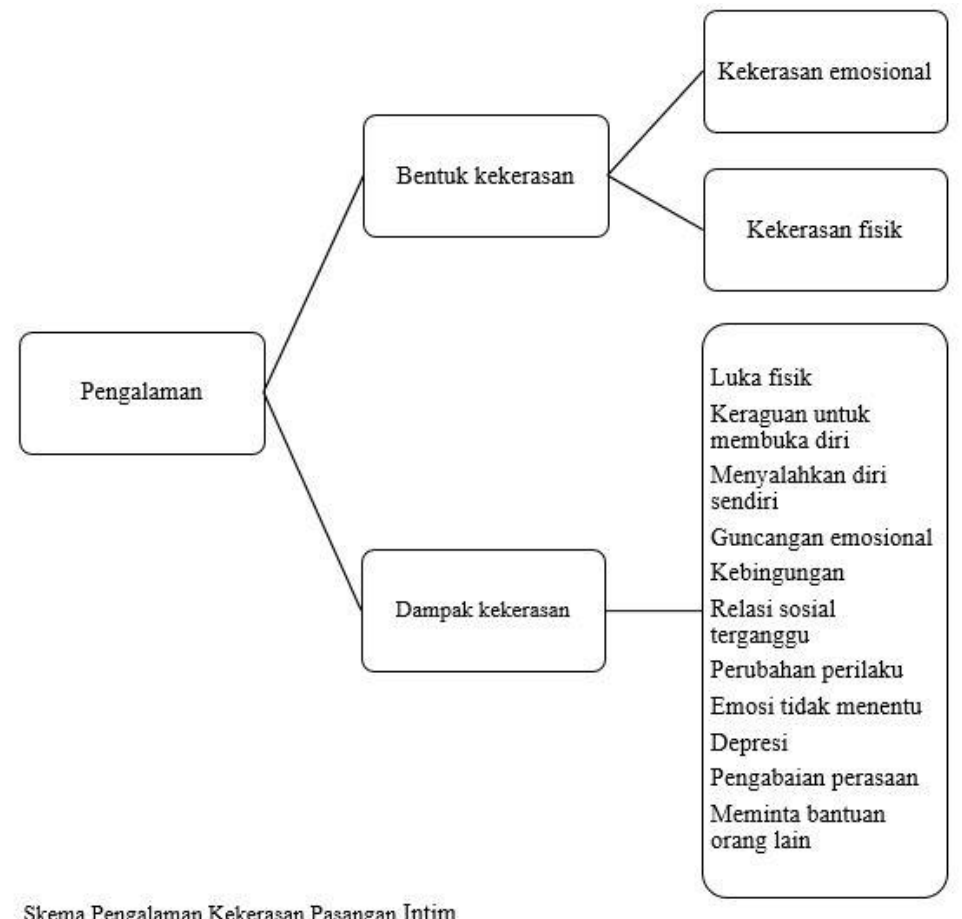

Skema Pengalaman Kekerasan Pasangan Intim

\section{Alasan subjek 1 bertahan}

Kerap mendapatkan tindakan kekerasan dari pasangan intim, membuat subjek memilih untuk tetap bertahan pada hubungan penuh kekerasan. Bagi subjek, pasangan merupakan orang pertama yang memberikan rasa cinta dan perhatian yang lebih. Selain karena merasa disayang, subjek dan keluarga pasangan sudah sangat dekat. Sehingga subjek sangat menyayangkan apabila hubungan tersebut berakhir. Subjek juga sangat menutup diri untuk laki-laki lain karena selain dilarang oleh pasangan, subjek menganggap bahwa semua laki-laki akan sama saja. Selain sedang menjalani hubungan yang cukup lama, subjek juga pertama kali melakukuan hubungan intim dengan pasangan sehingga subjek sangat berusaha mempertahankan hubungan tersebut. Subjek tidak menyukai hubungan yang putus nyambung.

Bagi subjek selama diri subjek masih kuat berada dalam hubungan tersebut subjek akan selalu mempertahankan. Subjek menganggap bahwa sebuah hubungan pasti memiliki dinamika yang naik dan turun. Maka dari itu meskipun terkadang adanya kelelahan, ketidakberdayaan, guncangan emosional, dan kesakitan, subjek memilih bertahan karena subjek menganggap pasangan subjek merupakan pasangan yang sangat baik. Sehingga subjek lebih memilih memperbaiki diri dan bertahan pada hubungan penuh kekerasan. 


\section{Alasan subjek 2 bertahan}

Kerap mendapatkan tindakan kekerasan dari pasangan, subjek sempat meminta untuk mengakhiri hubungan. Namun hal tersebut selalu gagal, karena pada akhirnya subjek memilih untuk kembali dan bertahan pada pasangan. Subjek merasa pasangan selalu bisa mengubah pikiran subjek. Subjek menganggap bahwa ucapan pasangan subjek sangat manipulatif. Subjek selalu berpikir mengapa subjek tidak bisa melawan perilaku pasangan. Ketika berargumen pun subjek selalu bisa dikalahkan oleh pasangan. Hal tersebut terkadang membuat subjek merasa lemah. Selain itu, alasan subjek memilih bertahan adalah subjek merasa pasangan masih menyimpan aib subjek. Yang mana subjek merasa takut apabila aib tersebut tersebar.

Di sisi lain, subjek merasa pasangan subjek sudah merupakan pasangan yang terbaik. Subjek sudah sangat merasa cocok dengan pasangan dan subjek beranggapan bahwa pacaran di usia subjek merupakan pacaran serius. Yang mana subjek telah memikirkan masa depan dengan pasangan. Keluarga subjek dan keluarga pasangan subjek juga sudah mengenal satu sama lain. Sehingga subjek memiliki harapan untuk selalu bersama pasangan hingga tahap selanjutnya. Meskipun teman-teman subjek menyarankan untuk mengakhiri hubungan tersebut, namun subjek tidak pernah mendengarkan saran tersebut dan memilih untuk bertahan. Subjek selalu yakin bahwa pasangan dapat berubah untuk mengontrol emosi dan tidak akan melakukan tindakan kekerasan.

\section{Alasan subjek 3 bertahan}

Bertahan pada hubungan kekerasan bukan lah hal yang mudah. Meskipun sering mengalami luka fisik dan terbatasinya hubungan sosial subjek, subjek tetap memilih bertahan pada pasangan. Bagi subjek, pasangan merupakan orang yang sangat baik melebihi siapapun. Subjek juga sangat respek dengan pasangan karena pasangan tidak melanggar prinsip subjek yaitu tidak akan melakukan hubungan seksual pra nikah. Permasalahan pada hubungan subjek dan pasangan selalu berasal dari faktor internal, tidak pernah ada orang ketiga dan faktor eksternal lainnya. Sehingga subjek merasa aman dan tentram ketika bersama pasangan, subjek juga tidak pernah merasa curiga pada pasangan. Subjek merasa pasangan merupakan satu-satunya orang yang dapat memahami subjek. Adanya persamaan latar belakang membuat subjek merasa sangat nyaman ketika bersama pasangan. Karena sama-sama berasal dari keluarga broken home, subjek merasa sangat dimengerti pengalaman dan perasaannya sebagai anak yang tidak tinggal bersama orang tua. Pasangan subjek sudah sangat dekat dengan keluarga subjek, begitu pula sebaliknya. Keluarga subjek sudah sangat percaya pada pasangan subjek dan subjek juga sangat diterima di keluarga pasangan Namun tidak ada yang mengetahui bahwa subjek merupakan korban kekerasan pasangan intim.

Subjek sangat bergantung pada pasangan dan subjek pun sadar jika pasangan membuat subjek bergantung pada pasangan. Subjek selalu menceritakan segala permasalahan yang subjek alami. Subjek akan merasa hancur dan sangat kehilangan ketika tidak bersama pasangan. Subjek menganggap bahwa pasangan sangat bisa dipercaya meskipun berperilaku sangat posesif. Namun di sisi lain terkadang muncul pemikiran pada subjek jika subjek bertahan dengan pasangan, maka mimpi-mimpi subjek akan hancur. Karena subjek selalu dibatasi dalam hal apapun. Sehingga berpikir bahwa tidak bisa meneruskan ke hubungan yang lebih serius meskipun subjek mengetahui bahwa pasangan subjek serius menjalin hubungan dengan subjek. Subjek telah memikirkan kesehatan mental pada anak subjek di masa yang akan datang. Meskipun subjek tidak memiliki keyakinan bahwa pasangan akan berubah, namun subjek tidak mempermasalahkan hal tersebut dan tetap menerima perilaku pasangan. 


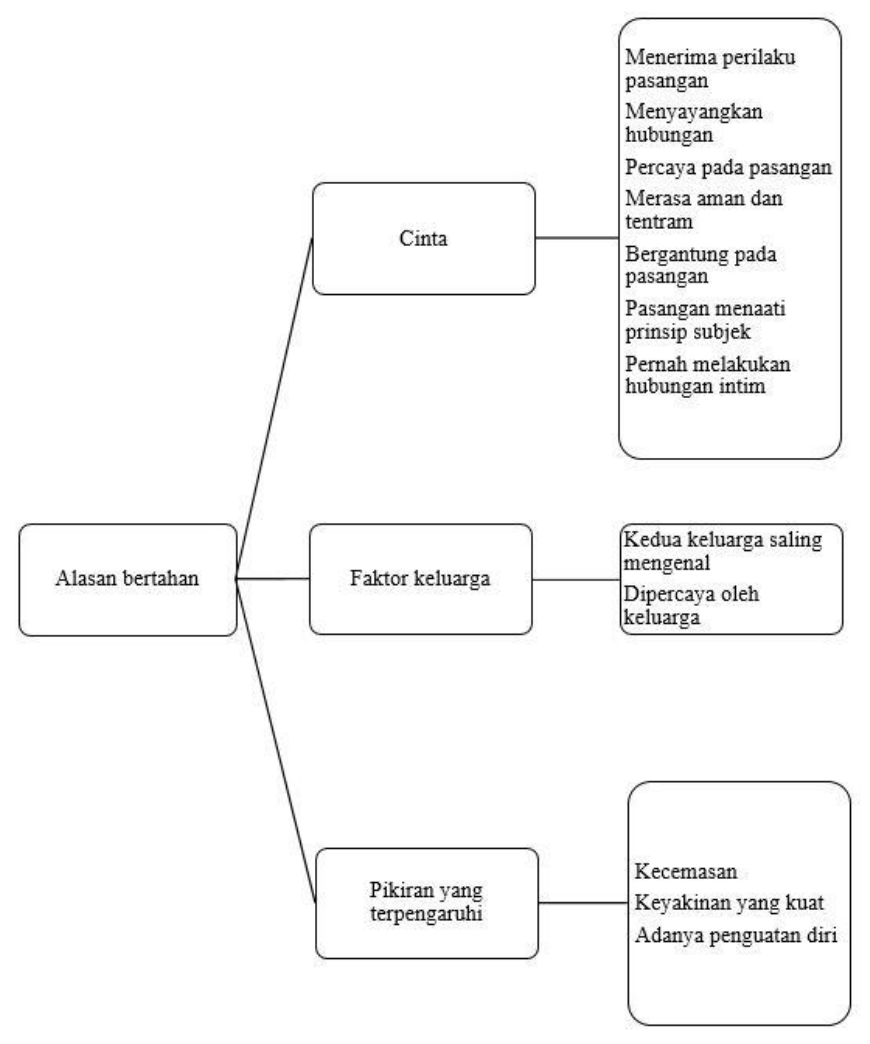

Skema alasan bertahan dalam hubungan

\section{Pemaknaan subjek 1 terhadap kekerasan}

Subjek beranggapan bahwa tindakan kekerasan yang dilakukan pasangan merupakan cara pasangan untuk menyayangi dan melindungi subjek agar tidak dekat dengan laki-laki lain. Subjek tidak terlalu memikirkan perasaan subjek ketika pasangan memberikan kekerasan verbal. Subjek berpikir bahwa ungkapan kata "pelacur" yang subjek terima merupakan hal yang wajar dan normal. Namun subjek merasa sedih ketika subjek mendapatkan kekerasan fisik, apalagi ketika terdapat bekas luka yang tidak kunjung sembuh. Subjek merasa bahwa hubungan yang subjek jalani saat ini merupakan hubungan yang paling berkesan. Subjek menerima dan memaklumi perilaku pasangan. Sehingga subjek selalu berusaha menjadi pribadi yang lebih baik. Di sisi lain, subjek juga selalu yakin bahwa manusia memiliki kekurangan dan kelebihan. Subjek sangat yakin bahwa pasangan akan berubah.

\section{Pemaknaan subjek 2 terhadap kekerasan}

Kerap kali mendapatkan tindakan kekerasan baik fisik maupun verbal, membuat subjek merasa bingung. Subjek sempat berpikir bahwa subjek tidak mungkin bisa bertahan dengan pasangan yang susah untuk mengontrol emosi. Subjek sadar bahwa subjek sedang berada dalam hubungan penuh kekerasan.

Namun di sisi lain subjek menganggap bahwa pasangan merupakan pasangan yang terbaik sehingga membuat subjek merasa sangat sulit untuk meninggalkan hubungan tersebut. Subjek beranggapan bahwa pasangan melakukan tindakan kekerasan karena pasangan ingin melindungi subjek. Meskipun subjek juga merasa terkontrol dengan perilaku dan permintaan pasangan, subjek selalu memaklumi perilaku tersebut. Subjek menganggap bahwa hubungan subjek merupakan hubungan paling berkesan. 
Dan dari pengalaman-pengalaman yang subjek alami, subjek merasa harus lebih unggul dibandingkan wanita lain. Subjek selalu berusaha untuk membuat pasangan terkesan pada subjek. Misalnya dengan memakai lipstik yang menurut subjek tidak cocok untuk subjek dan melakukan diet ketat. Hal tersebut dilakukan dengan harapan adanya perubahan pada pasangan, yang mana subjek tidak dibandingkan dengan wanita lain secara fisik. Subjek juga selalu berusaha untuk menjadi pribadi yang lebih sabar.

\section{Pemaknaan subjek 3 terhadap kekerasan}

Mendapatkan tindakan kekerasan verbal dan fisik membuat subjek berpikir bahwa kekerasan yang dilakukan pasangan dikarenakan pasangan berasal dari keluarga broken home. Subjek beranggapan bahwa perilaku pasangan berasal dari pengalaman masa lalu pasangan. Subjek berpikir bahwa tindakan kekerasan yang dilakukan pasangan merupakan cara pasangan melindungi dari lawan jenis yang berusaha mendekati subjek. Bagi subjek terkadang pasangan subjek marah karena hal yang tidak jelas.

Kerap mendapatkan tindakan kekerasan, justru membuat subjek untuk melindungi nama baik pasangan di depan teman-teman dan keluarga subjek. Setelah mendapatkan tindakan kekerasan, subjek dan

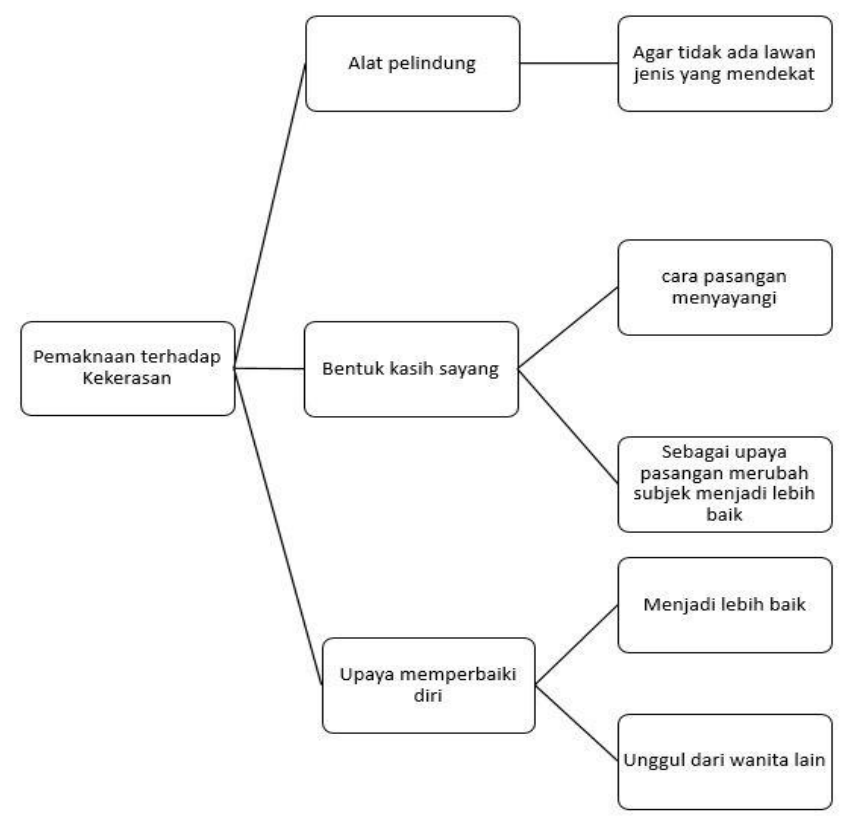

pasangan bersepakat untuk menutupi kejadian tersebut dan berpura-pura tidak terjadi apa-apa. Baik subjek dan pasangan tidak ingin menunjukkan bahwa adanya kekerasan dalam hubungan. Bagi subjek, pukulan yang diterima dari pasangan merupakan bentuk kasih sayang dari pasangan. Subjek menganggap pasangan ingin mengubah subjek menjadi pribadi yang lebih baik meskipun dengan cara kekerasan. Dan subjek pun menerima hal tersebut. Subjek juga beranggapan bahwa pasangan selalu ingin melindungi subjek dari lawan jenis yang berusaha mendekat.

\section{I S K U S I}

Subjek 1 (DA) menjadi korban kekerasan pasangan intim sejak enam bulan berpacaran dengan pasangan. Berawal dari kekerasan verbal seperti "pelacur" yang kemudian berkembang menjadi kekerasan fisik. Subjek pernah diperlakukan seperti pelacur dengan melempar beberapa jumlah uang setelah melakukan hubungan seksual. Subjek kerap mendapatkan cubitan, jambakan, gigitan, benturan, hingga pukulan. Subjek 2 (HF) menjadi korban kekerasan pasangan intim sejak enam bulan berpacaran

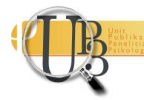


dengan pasangan. Berawal dari ejekan dan bentakan yang kemudian berkembang menjadi kekerasan fisik berupa tamparan dan jambakan. Subjek HF lebih sering mendapatkan kekerasan emosional dibandingkan kekerasan fisik. Subjek kerap dipaksa melakukan diet dan menggunakan pakaian terbuka demi kepuasan pasangan. Pasangan subjek juga kerap berselingkuh. Subjek 3 (AS) menjadi korban kekerasan pasangan intim sejak satu bulan berpacaran dengan pasangan. Berawal dari bentakan dan ejekan yang kemudian berkembang menjadi kekerasan fisik. Subjek kerap mendapatkan verbal "goblok", "gapunya otak", dan "lonte". Subjek juga kerap mendapatkan pukulan, benturan, injakan di leher hingga patah, serta tangan dan kaki subjek ditempelkan dengan benda panas hingga kulit subjek mengelupas.

Kekerasan emosional adalah setiap perilaku atau sikap non fisik yang dirancang untuk mengendalikan, menaklukkan, menghukum, atau mengisolasi orang lain melalui penghinaan. Kekerasan emosional dapat mencakup serangan verbal, dominasi, kontrol, isolasi, maupun ejekan. Kekerasan emosional seringkali merupakan awal dari kekerasan fisik. Kekerasan yang didapat oleh ketiga subjek berawal dari kekerasan emosional berupa verbal dan ejekan yang dilakukan pasangan dengan tujuan menghukum subjek karena melakukan tindakan yang tidak sesuai dengan keinginan pasangan (Carr, 2005). Seperti yang dilakukan subjek 1 yaitu menerima pesan singkat dari lawan jenis, yang dilakukan subjek 2 yaitu tidak melibatkan pasangan dalam sebuah proyek, dan yang dilakukan subjek 3 yaitu mendapatkan followers lawan jenis. Dan kekerasan fisik adalah cedera yang sengaja ditimbulkan dan menyebabkan adanya kerusakan tubuh seperti luka dan lebam. Subjek 1 mengalami luka tubuh berupa pendarahan bola mata kiri dan lebam pada tangan. Begitu pula dengan subjek 3 yang mengalami luka tubuh berupa patah leher, lebam, dan luka di beberapa bagian tubuh. Sedangkan subjek 2 tidak mengalami luka tubuh karena kekerasan fisik yang diterima tidak menimbulkan luka tubuh yang membekas.

Ketika mendapatkan perilaku kekerasan, awalnya subjek 1 kebingungan mengapa subjek bisa mendapatkan pukulan hanya karena masalah sepele yang membuat sering munculnya pertanyaan untuk diri subjek sendiri , seperti "kenapa sih aku dipukulin?", "aku kurang baik ta buat dia?". Hal ini menunjukkan adanya pikiran berulang pada subjek dan perasaan mengenai harga diri yang rendah. Subjek jarang untuk memberikan perlawanan namun terkadang memberikan perlawanan ketika merasa kesakitan. Hal ini subjek lakukan sebagai upaya melindungi diri. Konsekuensi psikologis jangka pendek seseorang yang mengalami kekerasan fisik meliputi keyakinan evaluasi diri yang negatif (meliputi: harga diri dan self-efficacy yang rendah), masalah dengan regulasi emosi, masalah terkait internalisasi (seperti: depresi, kecemasan, dan melukai diri sendiri), masalah perilaku eksternal (seperti: kemarahan yang tidak terkendali dan agresi), serta kesulitan menjalin hubungan (Carr, 2005). Hal tersebut juga dialami subjek 3, terkadang subjek merasa takut ketika akan bertemu dengan pasangan. Namun subjek tidak pernah memberikan perlawanan pada perilaku pasangan. Wanita yang menjadi korban kekerasan pasangan intim dapat mencari bantuan di berbagai tempat, beberapa di antaranya formal dan informal (Loue, 2002). Hal ini dilakukan oleh subjek 3 ketika mendapatkan tindakan kekerasan. Subjek 3 mencari bantuan ke psikolog dengan harapan dapat membantu mengubah perilaku pasangan.

Meskipun subjek 2 tidak memiliki luka fisik yang membekas, namun subjek 2 lebih merasakan dampak psikologis dari kekerasan pasangan intim. Subjek 2 merasa tertekan, kerap melukai diri sendiri, depresi, dan sempat ingin mengakhiri hidup. Depresi, bunuh diri, PTSD, penyalahgunaan alkohol, dan penyalahgunaan narkoba merupakan hal yang umum terjadi di antara wanita korban kekerasan. Bertahan dalam hubungan kekerasan juga dapat menggangu relasi sosial, yang mana hal ini dialami oleh ketiga subjek (Golding, 1999).

Kerap mendapatkan kekerasan pasangan intim tidak membuat korban ingin mengakhiri hubungan tersebut. Ketiga subjek memilih untuk bertahan dengan beberapa alasan. Hal yang membuat para korban memilih bertahan adalah karena adanya cinta dan faktor keluarga yang mana ketiga subjek

Buletin Riset Psikologi dan Kesehatan Mental (BRPKM)

2021, Vol. 1(1), 149-161 
sudah saling mengenal dan diterima di keluarga pasagan masing-masing, serta keluarga juga sudah saling percaya terhadap hubungan tersebut. Meskipun tidak ada yang mengetahui bahwa ketiga subjek merupakan korban kekerasan pasangan intim.

Bertahan dalam hubungan penuh kekerasan membuat korban memiliki keyakinan yang kuat bahwa pasangan akan berubah. Subjek 1 meyakini bahwa suatu saat pasangan akan berubah menjadi lebih baik. Subjek menganggap bahwa manusia memiliki kelebihan dan kekurangan masing-masing. Begitu pula dengan subjek 2 yang selalu meyakinkan diri bahwa pasangan akan berubah meskipun perlahan. Keyakinan tersebut semakin diperkuat dengan janji yang diberikan pasangan bahwa pasangan akan lebih mengontrol emosi dan tidak bermain tangan lagi. Berbeda dengan subjek 3, subjek tidak yakin pasangan akan berubah namun subjek tidak mempermasalahkan hal tersebut dan tetap menerima perilaku pasangan. Bagi ketiga subjek kekerasan yang dilakukan pasangan merupakan cara pasangan untuk melindungi subjek dari lawan jenis. Yang mana ketiga subjek memiliki kebutuhan atas rasa aman, dan subjek beranggapan hanya pasangan subjek yang dapat memberikan rasa aman tersebut. Selain itu kekerasan yang dilakukan pasangan merupakan bentuk kasih sayang serta upaya pasangan untuk merubah subjek menjadi lebih baik. Hal tersebut sejalan dengan penelitian yang dilakukan Khaninah \& Wdjanarko (2016) yang menyatakan bahwa wanita yang bertahan dalam hubungan penuh kekerasan selalu luluh dengan pasangan, memiliki harapan perilaku kasar pasangan akan berubah menjadi lebih baik, dan pasangan dapat merubah sikap subjek menjadi lebih baik.

Namun terdapat satu pemaknaan berbeda yang dimaknai oleh subjek 2. Subjek 2 selalu ingin berpenampilan seperti apa yang dikatakan pasangan. Seperti menggunakan lipstik yang tidak sesuai dan menggunakan pakaian terbuka. Hal tersebut dilakukan subjek untuk memberi kesan tersendiri bagi pasangan. Subjek 2 beranggapan bahwa jika mengikuti keinginan pasangan, maka subjek tidak akan dibandingkan dengan wanita lain. Wanita yang memiliki self-esteem yang rendah tidak melihat diri mereka cantik, oleh karena itu mereka tidak menganggap diri mereka layak sampai seorang pria membuktikan bahwa dia berharga bagi dirinya. Mereka tidak dapat hidup tanpa validasi pria, hal tersebut sangat berbahaya bagi wanita berusia 17-23 tahun (Špinarec, 2018). Artinya subjek 2 membutuhkan validasi dari pasangan untuk meningkatkan self-esteem dan merasa berharga untuk pasangan.

Ketiga subjek sadar sedang berada dalam hubungan kekerasan meskipun kerap mengalami luka fisik, kecemasan, merasa harga diri rendah, relasi sosial terganggu, hingga depresi. Subjek memaknai bahwa kekerasan yang dilakukan oleh pasangan merupakan bentuk kasih sayang, sebagai alat pelindung, dan cara untuk memperbaiki diri subjek menjadi lebih baik. Dalam fenomena pada ketiga subjek tersebut terlihat adanya ketidak konsistenan antara sikap dan pikiran subjek. Kognitif menunjuk pada setiap bentuk pengetahuan, pendapat, atau kepercayaan seseorang tentang lingkungan, diri sendiri, atau perilaku seseorang. Adanya ketidak konsitenan atau kesenjangan yang terjadi antara dua elemen kognitif sehingga menciptakan ketidaknyamanan psikologis yang akan memotivasi seseorang untuk mengurangi disonansi dan mencapai konsonansi, yang disebut sebagai disonansi kognitif (Festinger, 1957).

Disonansi kognitif menurut Vaughan \& Hoog merupakan suatu kondisi tidak nyaman dari tekanan psikologis ketika seseorang memiliki dua atau lebih kognisi (sejumlah informasi) yang tidak konsisten atau tidak sesuai satu sama lain. Yang mana dalam kasus tersebut, ketiga subjek mengetahui dan sadar telah menjadi korban kekerasan pasangan dengan segala konsekuensinya. Hal ini sebagai bentuk pengetahuan. Namun subjek memilih untuk tetap bertahan dalam hubungan penuh kekerasan tersebut. Hal ini sebagai bentuk sikap. Yang kemudian subjek memiliki keyakinan yang kuat bahwa: (1) pasangan akan berubah, (2) kekerasan sebagai bentuk kasih sayang, (3) kekerasan dilakukan untuk melindungi subjek, (4) kekerasan sebagai upaya untuk mengubah subjek menjadi lebih baik. Keyakinan-keyakinan tersebut merupakan cara ketiga subjek mengubah elemen kognitif lingkungan untuk mengurangi

Buletin Riset Psikologi dan Kesehatan Mental (BRPKM)

2021, Vol. 1(1), 149-161 
disonansi. Hal tersebut sejalan dengan teori Roger Brown yang memberi catatan bahwa dasar-dasar teori disonansi kognitif mengikuti prinsip-prinsip sederhana yaitu disonansi kognitif muncul ketika adanya ketidaknyamanan psikologis yang memotivasi seseorang untuk berusaha mencapai kesesuaian (Festinger, 1957).

\section{S I M P U L A N}

Berdasarkan hasil penelitian dan diskusi yang telah dijelaskan, ditemukan bahwa wanita masih kerap menjadi korban kekerasan pasangan intim yang dilakukan oleh pacar. Bentuk kekerasan yang diterima adalah kekerasan verbal yang berkembang menjadi kekerasan fisik. Hal ini menimbulkan bekas luka dan dampak psikologis seperti self-esteem rendah, menyalahkan diri sendiri, guncangan emosional, depresi, hingga memiliki keinginan untuk mengakhiri hidup, selain itu relasi sosial juga terganggu. Alasan subjek memilih bertahan dalam hubungan kekerasan adalah adanya cinta, adanya faktor keluarga, dan memiliki keyakinan bahwa pasangan akan berubah. Bagi subjek, kekerasan yang dilakukan oleh pasangan merupakan bentuk kasih sayang, sebagai upaya melindungi subjek dari lawan jenis, dan mengubah subjek menjadi lebih baik. Adanya ketidak konsistenan antara pengetahuan subjek (kesadaran menjadi korban kekerasan dengan segala konsekuensinya) dan sikap subjek (memilih bertahan dalam hubungan kekerasan) yang kemudian muncul keyakinan-keyakinan pada subjek untuk mencapai kesesuaian. Hal ini dapat disebut sebagai disonansi kognitif.

Berdasarkan hasil penelitian di atas, peneliti menyadari terdapat keterbatasan dalam penelitian ini, yaitu kurang mendalamnya data mengenai disonansi kognitif. Maka dari itu saran bagi peneliti selanjutnya yang tertarik membahas mengenai kekerasan dalam pasangan intim diharapkan dapat memperdalam bagaimana gambaran disonansi kognitif yang terjadi pada korban yang memilih bertahan dalam hubungan penuh kekerasan.

\section{U C A P A N T ER I MAKASIH}

Ucapan terima kasih penulis sampaikan kepada semua pihak yang tidak dapat penulis cantumkan satu per satu atas kontribusi yang telah diberikan dalam proses penelitian ini.

\section{DEKLARASI POTENSI TERJADINYAKONFLIKKEPENTINGAN}

Nirva Adeyusta Revaughanii dan Wiwin Hendrianani tidak bekerja, menjadi konsultan, memiliki saham, atau menerima dana dari perusahaan atau organisasi manapun yang mungkin akan mengambil untung dari diterbitkannya naskah ini.

\section{PUSTAKA ACUAN}

Brehm, Miller, Pelman, \& Campbell. (2002). Intimate Relationship. New York: McGraw-Hill. Carr, A. (2005). The Handbook of Child and Adolescent Clinical Psychology. New York: Routledge.

Estrellado, A. F., \& Loh, J. (. (2016). To Stay in or Leave an Abusive Relationship: Losses and Gains Experienced by Battered Filipino Women. Journal Interpersonal Violence, 1-21.

Festinger, L. (1957). A Theory of Cognitive Dissonance. California: Stanford University Press.

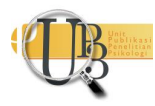


Golding, J. M. (1999). Intimate Partner Violence as a Risk Factor for Mental Disorders: A Meta-Analysis. Journal of Family Violence, 99-131.

Hasbiansyah, O. (2008). Pendekatan Fenomenologis: Pengantar Praktik Penelitian dalam Ilmu Sosial dan Komunikasi. 163-180.

Kahija, Y. L. (2017). Penelitian Fenomenologis: Jalan Memahami Pengalaman Hidup. Sleman: PT. KANISIUS.

Kementrian Pemberdayaan Perempuan dan Perlindungan Anak. (2018, Maret 20). KemenPPPA. Retrieved from www.kemenpppa.go.id: https://www.kemenpppa.go.id/index.php/page/read/31/1669/waspada-bahaya-kekerasandalam-pacaran

Khaninah, A. N., \& Widjanarko, M. (2016). Perilaku Agresif yang Dialami Korban Kekerasan dalam Pacaran. Jurnal Psikologi Undip, 151-160.

Komisi Nasional Anti Kekerasan Terhadap Perempuan. (2019, Maret 6). Komnas Perempuan. Retrieved from komnasperempuan.go.id: https://www.komnasperempuan.go.id/read-news-siaran-perscatatan-tahunan-catahu-komnas-perempuan-2019\%20

Loue, S. (2002). Intimate Partner Violence: Societal, Medical, Legal, and Individual Responses. New York: Kluwer Academic Publishers.

Putriana, A. (2018). Kecemasan dan Strategi Coping Pada Wanita Korban Kekerasan Dalam Pacaran (Studi Kasus di Samarinda). Psikoborneo, 691-703.

Sekarline, I., \& Margaretha. (2013). Stockhol Syndrome pada Wanita Dewasa Awal yang Bertahan dalam Hubungan yang Penuh Kekerasan. Jurnal Psikologi Klinis dan Kesehatan Mental, 1-6.

Špinarec, K. (2018). Toxic Relationship in New Adult Literature. Osijek: Digitalni Akademski Arhivi i Repozitoriji.

Stenberg, R. J., \& Weis, K. (Eds.). (2006). The New Psychology of Love. London: Yale Uniersity Press.

World Health Organization. (2013). World Health Statistics. France: World Health Organization. 